\title{
Attitudes of Small Business Owners towards Counterfeit Merchandise: Ethics or Survival?
}

\author{
Leanne L. Manley, Johannes A. Wiid, Michael C. Cant \\ University of South Africa (UNISA), South Africa \\ manlell@unisa.ac.za
}

\begin{abstract}
Counterfeiting of products is an industry that affects many countries worldwide and it is an industry that has grown exponentially in the $21^{\text {st }}$ century, due to the value associated with branded products. It is the demand from individuals that fuels this trade and what will keep the trade growing for years to come. It therefore becomes essential that research be conducted to investigate the attitudes held towards the trade in order to gain a better understanding of the current counterfeit environment. This article aimed to investigate the attitudes that South African small business owners have with regard to counterfeit merchandise. Quantitative research was undertaken by means of a self-administered web-based questionnaire that was e-mailed to individuals that either have an active SME (Small, Medium Enterprise) or individuals that are seeking to start their SME, who reside in the provinces of the Mpumalanga and the Western Cape. The data obtained was then analysed by means of SAS JMP version 11 whereby attitudes held towards counterfeit merchandise were established. The main conclusions emanating from the research, was that South African SMEs generally have a negative attitude towards purchasing counterfeit fashion branded merchandise.
\end{abstract}

Keywords: Brands, brand value, non-deceptive counterfeits, small businesses, attitudes, South Africa

\section{Introduction}

Counterfeiting, a trade that was once thought to be of minor significance, has grown at an alarming rate to be a serious economic, political and social issue, occurring in both developing and developed countries (Swami, Chamorro-Premuzic \& Furnham, 2009:820; Penz \& Ströttinger, 2005:568; Eisend \& Schuchert-Güler, 2006; De Matos, Ituassu \& Rossi, 2007:36). The illicit trade is said to have grown by over 10,000 per cent over the past two decades and accounts for approximately five to seven per cent of total world trade (between $\$ 500$ $\$ 600$ billion) (IACC, n.d.; Turunen \& Laaksonen, 2011:468; Kim \& Karpova, 2010:79; Yoo \& Lee, 2012:1507). Furthermore, the international chamber of commerce (ICC, n.d.) estimates the industry to grow to a projected $\$ 1.77$ trillion by 2015 with job loss projections to be around 2.5 million. Such data is however difficult to confirm due to the struggle in obtaining precise statistics (Swami et al., 2009:820). The phenomenal growth within the counterfeit industry can be attributed to many things, for example new technology, the increase in global trade, the internet which permits greater product dissemination, the development of new markets and the increase in products that have value in counterfeiting (Phau, Teah \& Lee, 2009:3; Phau \& Teah, 2009:15; le Cordeur, 2012) but more so it is the demand of consumers for such merchandise that fuels the continued success of the trade (Bian \& Moutinho, 2011:379) and one of the biggest threats counterfeiting has to the authentic brand market is that certain industries could ultimately find themselves in direct competition with the illicit traders (News24, 2011).

Academic literature indicates a strong research focus towards that of the supply side of the counterfeit industry, however leaving the demand aspect still relatively unknown (Penz \& Ströttinger, 2005:568; Heike, 2010:160; Lee \& Workman, 2011:290; Vida, 2007:254). Furthermore, few studies have examined consumer behaviour and attitudes regarding counterfeit products (Bian \& Veloutsou, 2007:211), essentially the "...learned predisposition to behave in a consistently favourable or unfavourable way toward market-related objects, events or situations" (Cant, 2010:46) and even less have focussed on behavioural habits of consumers residing within African markets and in particular small business owners' attitudes towards the purchase of such merchandise in South Africa. Therefore, this research sought to fulfil this gap within academic literature, by establishing small business owners' attitudes towards counterfeit merchandise in South Africa. Through revealing insights into the attitudes, motivations and determinants of counterfeit purchase behaviour, Koklic, 
(2011:127) as well as Kim and Karpova (2010:80) state that worthwhile public policy could essentially be developed. Bian and Moutinho (2009:369) further state that through identification of counterfeit purchase determinants, marketers might be able to set up more effective and sophisticated marketing strategies. The next section provides a brief background into the counterfeit trade, counterfeiter's attraction to African markets, the counterfeiting issues arising in South Africa and the attitude towards counterfeit merchandise which is then followed by the aims and objectives of the article. Lastly, a brief description as to research methodology employed is discussed followed by a discussion as to the research findings, conclusions, recommendations and limitations.

\section{Literature Review}

Counterfeit Trade: The word counterfeit is a term that can be seen to be synonymous with fake, imitation, knock-off, copy and replica (Juggessur \& Cohen, 2009:390; Nellis, 2011) and can be defined according to Teah and Phau (2001:1) as "...the reproduction or replicated version of genuine article". Counterfeit merchandise can be divided into two categories known as deceptive counterfeit products and non-deceptive counterfeit products (Juggessur \& Cohen, 2009:390). Deceptive counterfeit products are those products that intentionally mislead the consumer into believing they are purchasing the authentic product while nondeceptive counterfeit products are those products which consumers know to be non-authentic due to price, quality and method of distribution, yet purchase them anyway (Zhang, Hong \& Zhang, 2012:50; Penz \& Ströttinger, 2005:568; Heike, 2010:161). For the purpose of this study non-deceptive counterfeiting was investigated as according to Bian and Moutinho (2009:93) it is only under these situations that consumer perceptions and/or attitudes will reflect their demand.

The counterfeit industry is said to affect a wide array of products and virtually leaves no product category unscathed (Bian \& Veloutsou, 2007:212; Ang, Cheng, Lim \& Tambyah, 2001:221). According to Penz and Ströttinger (2005:568), the preferred target markets for counterfeiters are companies that carry high brand image and require a relatively simple production method for their products. The reason pertaining to this is that a company's brand is often its most valuable asset and if it is successful the brand will most often be susceptible to counterfeit practices (Maldonado \& Hume, 2005:105). One of the most prominently affected industries of counterfeit trade, is that of the fashion branded products as this is a very lucrative market, among which clothing, shoes, watches, leather goods, and jewellery are among the top affected products (Harun, Bledram, Suki \& Hussein, 2012:15; Phau, Sequeira \& Dix, 2009:262; Ergin, 2010:2181-2186). Therefore, for the purpose of this research attitudes held toward counterfeit fashion branded merchandise were investigated.

Counterfeit merchandise can furthermore be traced all over the world, but what has become very apparent is that the act of counterfeiting is particularly widespread in Asia (Ang et al., 2001:221). According to Bian and Veloutsou (2007:213) and Phau and Teah (2009:15) China is notoriously known to be one of the major producers of counterfeit merchandise and is the country where all sources of counterfeit merchandise can be traced. Bian and Veloutsou (2007:213) further go on to state that China exports counterfeit merchandise globally to Europe, Russia, the Middle East and the United States of America, but what has become a new trend in the eyes of counterfeiters is to utilise Africa as a "transit route"; through utilising Africa, merchandise is rerouted in order to disguise the producer's country of origin (Meissner, 2010). The following section will further discuss the attraction counterfeiters have had to Africa.

Counterfeiters Attraction to African Markets: Not only can country of origin be disguised through the use of African markets, but Meissner (2010) further points out that the attraction to African markets for counterfeiters is due to increasing trade links established between Africa and China, where porous borders are found. Also, African governments do not share data with regard to counterfeit goods and probably most importantly, most African consumers do not regard the trading of counterfeit merchandise to be a serious crime (Meissner, 2010). A further key driving factor, according to Haman (2010:345), which adds to Africa's counterfeit problems are that of socio-economic factors, whereby poverty and unemployment guarantee that there are enough individuals that need to make a living by any means necessary. This consequently means that individuals could be subject to trading directly or indirectly with counterfeit merchandise in order to support themselves and their families. 
Counterfeiting Issues Arising in South Africa: Like all nations, South Africa is no exemption to counterfeit trade, according to the South African Institute for Intellectual Property Law (SAIIPL, [n.d.]), South Africa in particular is being targeted by counterfeiters as a "dumping ground" and "transit route" as the country is not landlocked like other African countries and furthermore the country has many ports for which counterfeiters can dock at to off load merchandise (Haman, 2010:345). According to du Plessis (In: le Cordeur, 2012), counterfeiting of merchandise in South Africa is a somewhat new problem, most likely brought about due to the countries past political isolation and due to luxury products (products counterfeiters target most), being regarded for the well-off and those that had sufficient funds to travel abroad (le Cordeur, 2012). Post political isolation however, South African borders became more permeable, trade relationships were established and well-known brands became more available in the country, making South African consumers more brand conscious (le Cordeur, 2012).

Ramara and Lamont (2012) state that, the act of counterfeiting in South Africa is regarded as a victimless offense to many, and one that it is viewed as a chance to get a desired branded product at a far lower price to that of the authentic. According to Magwaza (2012), South Africa has seen a solid increase in the amount of street vendors trading counterfeit clothing; this act has therefore affected the country in a detrimental way, whereby jobs as well as revenue for clothing manufacturers have been lost. Singh (In News24, 2011) notes that the South African counterfeit trade industry is valued at around R362 billion, and is regarded as one of the world's fastest growing trades. Ramara and Lamont (2012) indicate that in 2010 a projected 14,400 South Africans lost their jobs in the textile industry as a result of counterfeit clothing being imported. Magwaza (2012) asserts that, in 2011, 20,000 seizures were made by the South African Revenue Service which can be seen to be valued at R1 billion, whereby 750,000 pieces of clothing were seized to the value of R483 million. Even though government authorities and industries fight to restrain this illegal activity, counterfeits are in the market because there is a demand by consumers (Kim \& Karpova, 2010:80). Therefore, in order to understand this demand, research into the attitudes of businesses and consumers becomes essential.

Attitude Towards Counterfeit Merchandise: The concept of attitude is frequently utilised by marketers as a forecaster of consumer intentions and behaviours (Phau, Sequeira \& Dix, 2009:263), and it is an important construct in the study of counterfeit purchase behaviour however it is a section within literature that has received very little attention (Sharma \& Chan, 2011:605). Attitude, according to Yoo and Lee (2009:280), refers to "...the degree to which a person has a favourable appraisal of the behaviour in question and are an immediate indicator by which his/her intention of conducting a specific behaviour can be predicted". Mir (2011:51-52) further states that attitudes “... are an individual's internal evaluations of the objects or events based on his or her beliefs". Furthermore, attitudes are what guide consumers to make a response within their environment and provides them with reasons to perform the specific act. Lan, Lui, Fang and Lin (2012:290) indicate that a consumer's intention to purchase counterfeit products is dependent on a consumer's attitude towards the counterfeit merchandise. Therefore, according to Yoo and Lee (2009:280) if consumers have positive attitudes toward buying counterfeit products it is expected to positively affect their purchase intention towards counterfeits. Due to the fact that attitudes cannot be directly observed, marketers must depend on determining consumers' attitudes through research (Phau, Sequeira \& Dix, 2009:263). This research evaluates consumer's attitudes towards counterfeit products through the evaluation of consumer past purchases and factors that influence the decision to purchase counterfeit products.

Aim and Objectives of the Research: The primary objective of the study was to determine the attitudes held by Small Medium Enterprise (SME) owners in relation to the purchase of counterfeit fashion merchandise. In order to ascertain this primary objective the following secondary research objectives were formulated.

- To determine what fashion branded counterfeit products are being purchased

- To explore the relationship between positive attitudes of buying counterfeit products and biographical profiles

- To explore the relationship between negative attitudes of buying counterfeit products and biographical profiles

- To investigate factors influencing the decision to purchase counterfeit fashion branded products 


\section{Methodology}

In determining the attitudes held by SME owners in relation to the purchase of counterfeit fashion merchandise a questionnaire was developed for this study. The questionnaire mostly incorporated questions that were quantitative in nature. An online survey questionnaire (Survey Monkey) was used to collect the data from entrepreneurs and potential entrepreneurs in the South African provinces of Mpumalanga and the Western Cape. A sufficient number of questionnaires were sent out for a confidence level of 95 per cent and a confidence interval of 10. A total of 73 usable responses were received, giving a 95 per cent confidence level and a 10.89 confidence interval at 50 per cent. The demographic profile of the majority of respondents (32.76 per cent) was between 25 and 34 years of age. The gender split for the respondent group was male dominated, with 63.16 per cent of respondents being male. Most of the respondents were African (57.41 per cent), and most respondents had a matric qualification. Respondents were evenly spread over business sectors, while residing mostly in Mpumalanga (42.11 per cent) and the Western Cape (50.88 per cent). The demographic profile of the respondent group is presented in Table 1 below:

Table 1: Demographic Profile of Respondents

\begin{tabular}{llllll}
\hline & \% of Total & $\mathbf{N}$ & & \% of Total & N \\
\hline Age group & & & Business sector & & \\
$18-24$ & 13.79 & 8 & Banks/insurance & 6.00 & 3 \\
$25-34$ & 32.76 & 19 & Business services & 30.00 & 15 \\
$35-44$ & 20.69 & 12 & Construction & 12.00 & 6 \\
$45-54$ & 25.86 & 15 & Food/Catering & 16.00 & 8 \\
$55-64$ & 6.90 & 4 & IT & 8.00 & 4 \\
Gender & & & Manufacturing & 12.00 & 6 \\
Female & 36.84 & 21 & Retail & 10.00 & 5 \\
Male & 63.16 & 36 & Transport & 6.00 & 3 \\
Highest qualification & & & Residing province & & \\
Certificate & 21.05 & 12 & Gauteng & 1.75 & 1 \\
Degree & 14.04 & 8 & Limpopo & 1.75 & 1 \\
Diploma & 19.30 & 11 & Mpumalanga & 42.11 & 24 \\
Doctorate & 5.26 & 3 & The Northern Cape & 3.51 & 2 \\
Matric & 28.07 & 16 & The Western Cape & 50.88 & 29 \\
Post graduate degree & 12.28 & 7 & & & \\
\hline
\end{tabular}

Table 2: Counterfeit Products Purchased

\begin{tabular}{llllll}
\hline Item & $\begin{array}{l}\text { Total } \\
\text { Responses }\end{array}$ & $\begin{array}{l}\text { NO } \\
\text { \% of Total }\end{array}$ & $\mathbf{N}$ & $\begin{array}{l}\text { YES } \\
\text { \% of Total }\end{array}$ & N \\
\hline Watches & 73 & 89.0 & 65 & 11.0 & 8 \\
Sunglasses & 73 & 87.7 & 64 & 12.3 & 9 \\
Shoes & 73 & 93.2 & 68 & 6.8 & 5 \\
Pants & 73 & 90.4 & 66 & 9.6 & 7 \\
Shirts & 73 & 90.4 & 66 & 9.6 & 7 \\
Shorts & 73 & 100 & 73 & 0.0 & 0 \\
Skirts & 73 & 97.3 & 71 & 2.7 & 2 \\
Jackets & 73 & 95.9 & 70 & 4.1 & 3 \\
Handbags & 73 & 90.4 & 66 & 9.6 & 7 \\
Wallet & 73 & 94.5 & 69 & 5.5 & 4 \\
Jewellery & 73 & 90.4 & 66 & 9.6 & 7 \\
\hline
\end{tabular}




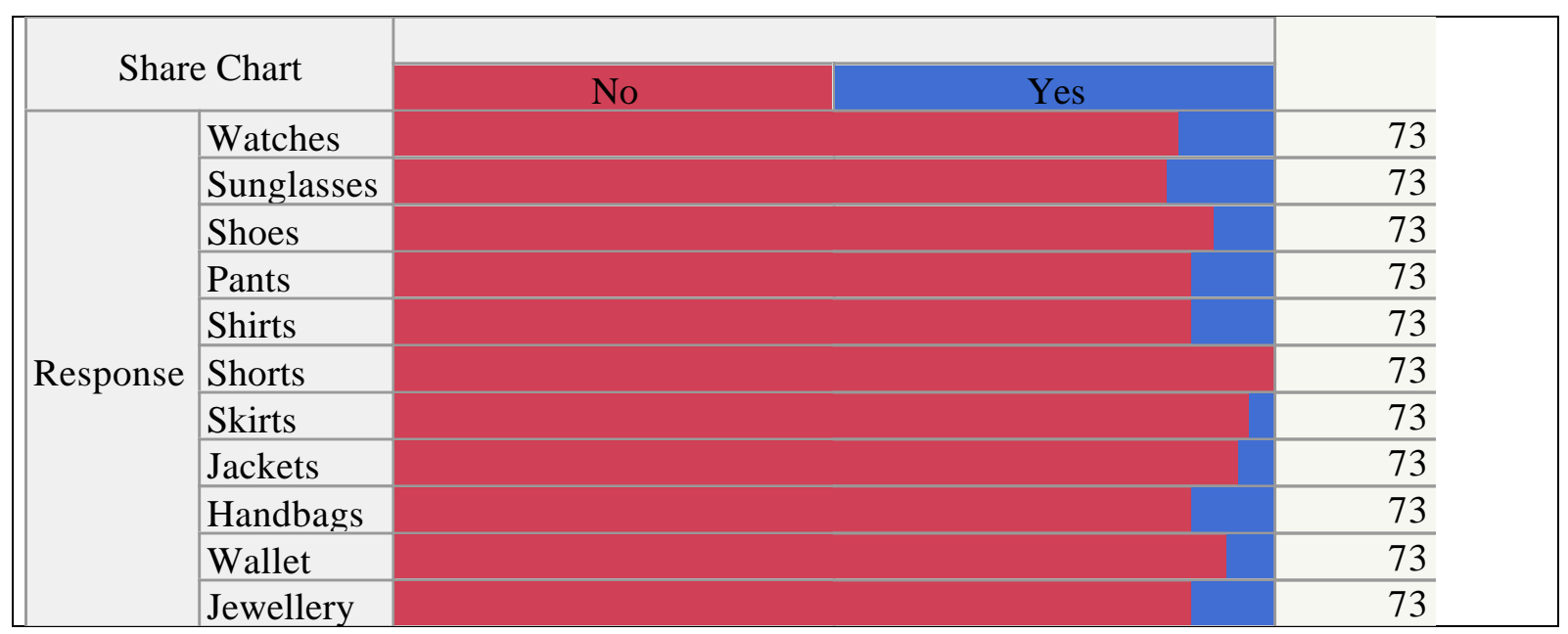

\section{Findings and Discussion}

Past purchase behaviour of SME Owners towards Counterfeit Products: To determine what kind of counterfeit products have been purchased in the past, respondents were asked to indicate all the products that they previously bought. Table 2 below is indicative of the results obtained:

From the results obtained it can be seen that most SME owners purchased counterfeit sunglasses (12.3 per cent) followed by watches (11 per cent) while none had purchased counterfeit shorts.

Factors that influence decision to purchase counterfeit products: To determine the attitudes of respondents on the factors influencing the decision to purchase a counterfeit, respondents were asked to rate five statements on a five-point Likert scale ( 1 being "Most important" and 5 being "Least important"). For interpretation purposes the scale was collapsed to a three-point scale by combining statements 4 and 5 as "most important", and statements 1 and 2 as "least important". Table 3 below indicates the results obtained:

Table 3: Factors Influencing Counterfeit Purchase Decision

\begin{tabular}{|c|c|c|c|c|c|c|c|}
\hline \multirow{2}{*}{ Factors } & \multicolumn{2}{|c|}{ Most important } & \multicolumn{2}{|l|}{ Neither } & \multicolumn{2}{|c|}{ Least important } & \multirow[t]{2}{*}{$\begin{array}{l}\text { Total } \\
\text { Responses }\end{array}$} \\
\hline & \multicolumn{2}{|c|}{$\%$ of Total } & $\%$ of Total & $\mathbf{N}$ & $\%$ of Total & $\mathbf{N}$ & \\
\hline Price & 69.0 & 29 & 9.5 & 4 & 21.4 & 9 & 42 \\
\hline Quality & 50.0 & 21 & 23.8 & 10 & 26.2 & 11 & 42 \\
\hline Design & 65.1 & 28 & 11.6 & 5 & 23.3 & 10 & 43 \\
\hline Social status & 45.0 & 18 & 17.5 & 7 & 37.5 & 15 & 40 \\
\hline Brand loyalty & 46.3 & 19 & 9.8 & 4 & 43.9 & 18 & 41 \\
\hline \multirow{2}{*}{\multicolumn{2}{|c|}{ Share Chart }} & \multirow{7}{*}{ Most imp } & & \multirow[b]{2}{*}{ Neither } & \multirow{3}{*}{\multicolumn{2}{|c|}{ Least important }} & \\
\hline & & & $\mathrm{Ne}$ & & & & \\
\hline \multirow{5}{*}{ Response } & Price & & & & & & 42 \\
\hline & Quality & & & & & & 42 \\
\hline & Design & & & & & & 43 \\
\hline & $\begin{array}{l}\text { Social } \\
\text { status }\end{array}$ & & & & & & 40 \\
\hline & $\begin{array}{l}\text { Brand } \\
\text { loyalty }\end{array}$ & & & & & & 41 \\
\hline
\end{tabular}

From Table 3 above it can be seen that, price is considered by most of the respondents to be the most important factor followed, by design. However, when respondents are split between respondents that have purchased and those that have not purchased a counterfeit product, a different pattern emerges. This pattern can be viewed in Table 4 below: 
Table 4: Factors Influencing Purchase Decision Versus Purchase and Not Purchased

\begin{tabular}{|c|c|c|c|c|c|c|c|c|c|}
\hline \multirow{2}{*}{ Factor } & \multirow[b]{2}{*}{ Purchased } & \multicolumn{2}{|c|}{ Most Important } & \multicolumn{2}{|c|}{ Neutral } & \multicolumn{2}{|c|}{ Least Important } & \multirow{2}{*}{\multicolumn{2}{|c|}{ Total Responses }} \\
\hline & & $\begin{array}{l}\text { d of } \\
\text { Total }\end{array}$ & & $\begin{array}{l}\% \text { of } \\
\text { Total }\end{array}$ & $\mathbf{N}$ & $\%$ of Total & $\mathbf{N}$ & & \\
\hline \multirow{2}{*}{ Price } & No & $\begin{array}{ll}50.0 \quad 8\end{array}$ & & 12.5 & 2 & 37.5 & 6 & 16 & \\
\hline & Yes & 79.2 & & 8.3 & 2 & 12.5 & 3 & 24 & \\
\hline \multirow{2}{*}{ Quality } & No & 70.6 & & 0 & 0 & 29.4 & 5 & 17 & \\
\hline & Yes & 34.8 & & 39.1 & 9 & 26.1 & 6 & 23 & \\
\hline \multirow{2}{*}{ Design } & No & 58.8 & & 5.9 & 1 & 35.3 & 6 & 17 & \\
\hline & Yes & 66.7 & & 16.7 & 4 & 16.7 & 4 & 24 & \\
\hline \multirow{4}{*}{$\begin{array}{l}\text { Social } \\
\text { status } \\
\text { Brand } \\
\text { loyalty }\end{array}$} & No & 43.8 & & 18.8 & 3 & 37.5 & 6 & 16 & \\
\hline & Yes & 45.5 & & 18.2 & 4 & 36.4 & 8 & 22 & \\
\hline & No & 56.3 & & 0 & 0 & 43.8 & 7 & 16 & \\
\hline & Yes & 34.8 & & 17.4 & 4 & 47.8 & 11 & 23 & \\
\hline \multicolumn{4}{|c|}{ Share Chart } & \multicolumn{2}{|c|}{ Important } & Neutral & \multicolumn{2}{|c|}{ Not important } & \\
\hline \multirow{10}{*}{ Response } & \multirow[b]{2}{*}{ Price } & \multirow{2}{*}{$\begin{array}{l}\text { Q2 Have you } \\
\text { ever purchased } \\
\text { a counterfeited } \\
\text { product? }\end{array}$} & No & Impc & & Neutral & No & ortant & 16 \\
\hline & & & Yes & & & & & & 24 \\
\hline & \multirow[b]{2}{*}{ Quality } & \multirow{2}{*}{$\begin{array}{l}\text { Q2 Have you } \\
\text { ever purchased } \\
\text { a counterfeited } \\
\text { product? }\end{array}$} & No & & & & & & 17 \\
\hline & & & Yes & & & & & & 23 \\
\hline & \multirow{2}{*}{ Design } & \multirow{2}{*}{$\begin{array}{l}\text { Q2 Have you } \\
\text { ever purchased } \\
\text { a counterfeited } \\
\text { product? }\end{array}$} & No & & & & & & 17 \\
\hline & & & Yes & & & & & & 24 \\
\hline & \multirow{2}{*}{$\begin{array}{l}\text { Social } \\
\text { status }\end{array}$} & \multirow{2}{*}{$\begin{array}{l}\text { Q2 Have you } \\
\text { ever purchased } \\
\text { a counterfeited } \\
\text { product? }\end{array}$} & No & & & & & & 16 \\
\hline & & & Yes & & & & & & 22 \\
\hline & \multirow{2}{*}{$\begin{array}{l}\text { Brand } \\
\text { loyalty }\end{array}$} & \multirow{2}{*}{$\begin{array}{l}\text { Q2 Have you } \\
\text { ever purchased } \\
\text { a counterfeited } \\
\text { product? }\end{array}$} & No & & & & & & 16 \\
\hline & & & Yes & & & & & & 23 \\
\hline
\end{tabular}

Respondents that have purchased a counterfeit product consider price as the most important factor, followed by design. Respondents that have NOT purchased a counterfeit product consider quality as the most important factor followed by brand loyalty. When collapsing "most important" and "least important" as "important" and "not important", seemingly ${ }^{1}$ significant associations for quality and design are shown. See Table 5 below:

Table 5: Significance of the Factors that Influence the Decision to Purchase

\begin{tabular}{lllll}
\hline Factor & Chi-Square value & DF & P-value & Significance \\
\hline Price & 4.043 & 2 & 0.1324 & Not Significant \\
Quality & 9.198 & 2 & 0.0101 & Seems to be Significant \\
Design & 2.461 & 2 & 0.2921 & Not Significant \\
Social status & 0.011 & 2 & 0.9946 & Not Significant \\
Brand loyalty & 3.814 & 2 & 0.1485 & Not Significant \\
\hline
\end{tabular}

From Table 5, a seemingly significant association exists between question 2 (Have you ever purchased a counterfeit product?) and question 4 (Quality).

\footnotetext{
${ }^{1}$ Please note that the assumption of expected cell size $>=5$ is violated.
} 
Table 6: Quality By Q2, Have You Ever Purchased a Counterfeited Product?

\begin{tabular}{lllll}
\hline & & No & Yes & Total \\
\hline \multirow{4}{*}{ Important } & Count & 12 & 8 & 20 \\
& Total \% & 30.00 & 20.00 & 50.00 \\
& Column \% & 70.59 & 34.78 & \\
& Row \% & 60 & 40.00 & \\
Neutral & Count & 0 & 9 & 9 \\
& Total \% & 0.00 & 22.50 & 22.50 \\
& Column \% & 0.00 & 39.13 & \\
\multirow{5}{*}{ Not important } & Row \% & 0.00 & 100 & \\
& Count & 5 & 6 & 11 \\
\multirow{5}{*}{ Total } & Total \% & 12.50 & 15.00 & 27.50 \\
& Column \% & 29.41 & 26.09 & \\
& Row \% & 45.45 & 54.55 & \\
& Count & 17 & 23 & 40 \\
& Total \% & 42.50 & 57.50 & 100 \\
\hline
\end{tabular}

Clearly the proportion of respondents that have purchased a counterfeit product is much higher for the neutral group of quality $(9 / 9=100$ per cent) than the other categories (important: $8 / 20=40$ per cent and not important: $6 / 11=54.55$ per cent). The conclusion could be made that the proportion of respondents that purchased a counterfeit product are much higher for the neutral category than the other categories.

Attitude of Small Business Owners towards the Purchase of Counterfeits: To determine the attitudes of SME owners regarding the purchase of a counterfeit; respondents were asked to rate 12 statements on a fivepoint Likert scale ( 1 being "strongly agree" and 5 being "strongly disagree"). For interpretation purposes the scale was collapsed to a three-point scale combining statement 1 and 2 as "agree", and statement 5 and 6 as "disagree". Table 7 below is indicative as to the results obtained:

Table 7: Attitude Statements and Share Chart ${ }^{2}$

\begin{tabular}{|c|c|c|c|c|c|c|c|}
\hline \multirow{2}{*}{ Statements } & \multicolumn{2}{|l|}{ Disagree } & \multicolumn{2}{|l|}{ Neither } & \multicolumn{3}{|l|}{ Agree } \\
\hline & $\%$ of Total & $\mathbf{N}$ & $\%$ of Total & $\mathbf{N}$ & $\%$ of Total & $\mathbf{N}$ & Mean \\
\hline Considering price, I prefer counterfeit goods & 58.49 & 31 & 16.98 & 9 & 24.53 & 13 & 1.66 \\
\hline I like shopping for counterfeit goods & 88.68 & 47 & 7.55 & 4 & 3.77 & 2 & 1.15 \\
\hline $\begin{array}{l}\text { Buying counterfeit goods generally benefits } \\
\text { the consumer }\end{array}$ & 59.62 & 31 & 23.08 & 12 & 17.31 & 9 & 1.58 \\
\hline $\begin{array}{l}\text { There's nothing wrong with purchasing } \\
\text { counterfeit goods }\end{array}$ & 66.04 & 35 & 24.53 & 13 & 9.43 & 5 & 1.43 \\
\hline $\begin{array}{l}\text { Generally speaking, buying counterfeit } \\
\text { goods is a better choice }\end{array}$ & 73.08 & 38 & 21.15 & 11 & 5.77 & 3 & 1.33 \\
\hline $\begin{array}{l}\text { Counterfeits have similar quality to the } \\
\text { original version }\end{array}$ & 71.70 & 38 & 15.09 & 8 & 13.21 & 7 & 1.42 \\
\hline $\begin{array}{l}\text { Buying counterfeits infringes intellectual } \\
\text { property }\end{array}$ & 20.75 & 11 & 11.32 & 6 & 67.92 & 36 & 2.47 \\
\hline Buying counterfeits will hurt the industry & 18.52 & 10 & 9.26 & 5 & 72.22 & 39 & 2.54 \\
\hline
\end{tabular}

\footnotetext{
$2 *$ Please note that a few of the mentioned statements were derived from De Matos et al (2007) and Riquelme, Abbas \& Rios (2012).
} 
Buying counterfeits damages interests and 14.81

Purchasing counterfeits is illegal

Counterfeit products have the same 66.04

attributes as the original product

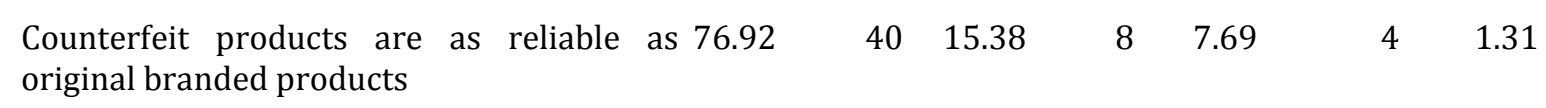

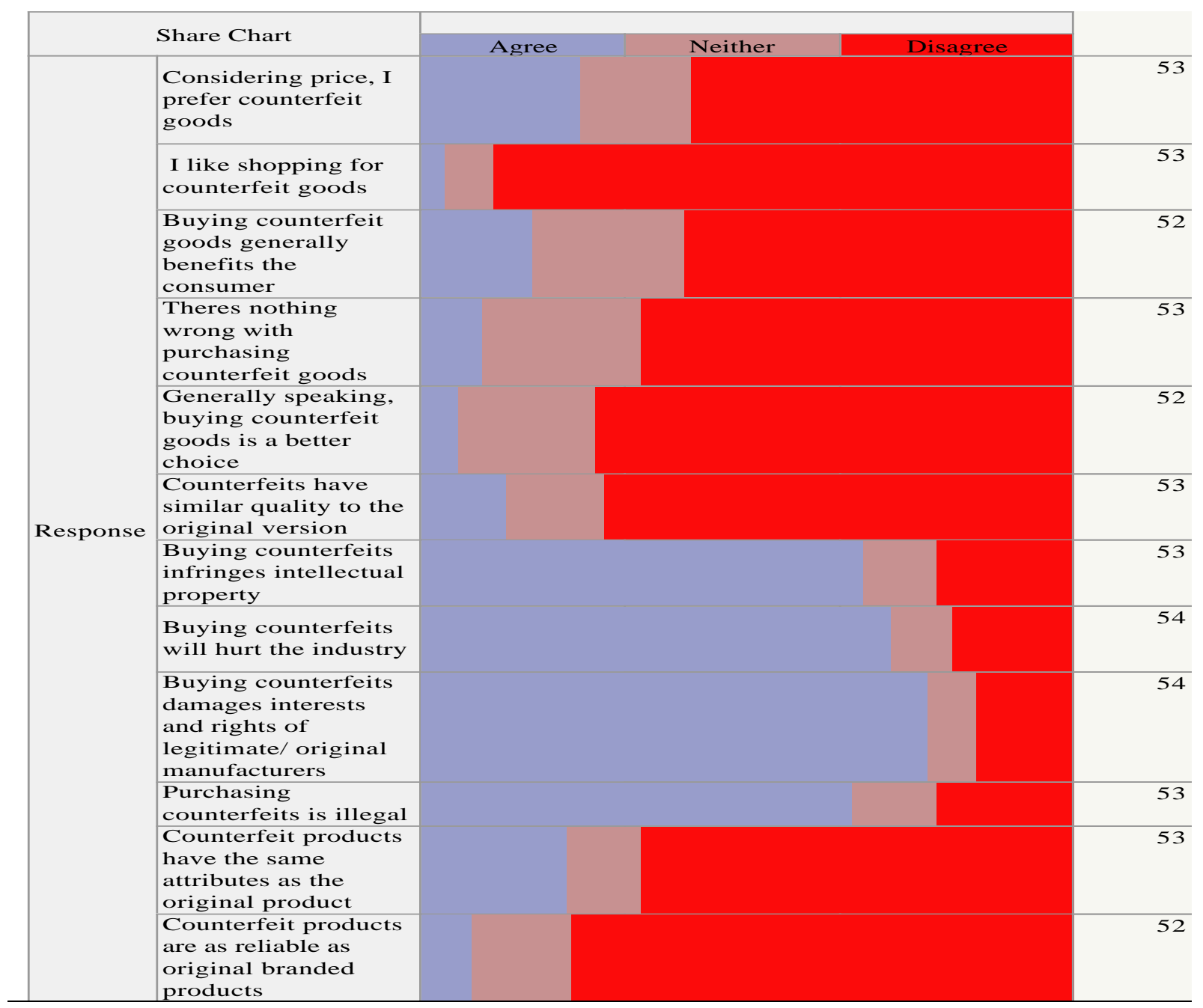

It is clear from the table above that the majority (88.68 per cent) of SME owners do not like shopping for counterfeit goods. More than three quarters (77.78 per cent) agreed that buying counterfeits damage the interests and rights of legitimate/original manufacturers. A large portion (76.92 per cent) see counterfeits as not as reliable as original branded products. Almost three quarters (73.08 per cent) share the view that in general, buying counterfeit goods is not a better choice. A large portion of the sample (72.22 per cent) is of the opinion that buying counterfeits will hurt the industry.

An exploratory factor analysis was done on these statements (Table 8) to group attitudes towards counterfeit products. The principal components method was used to extract the components, and this was followed by a Varimax (orthogonal) rotation. Only the first two components exhibited Eigen values greater than or near 1 and results of a screen test also suggested that only the first two were meaningful. Therefore, only the first two components were retained for rotation. Combined, the first two components accounted for 67 per cent of 
the total variance. Questionnaire items and corresponding factor loadings are presented in Table 8 below. In interpreting the rotated factor pattern, an item was said to load on a given component if the factor loading was 0.40 or greater for that component and less than 0.40 for the other. Using these criteria, eight items were found to load on the first component, which was subsequently labelled "Personal agenda". Four items loaded on the second component, labelled "Legal issues".

Table 8: Rotated Factor Loadings ${ }^{3}$

\begin{tabular}{lll}
\hline Statement & Factor 1 & Factor 2 \\
\hline Considering price, I prefer counterfeit goods & $\mathbf{0 . 8 5}$ & 0.14 \\
I like shopping for counterfeit goods & $\mathbf{0 . 7 3}$ & 0.06 \\
Buying counterfeit goods generally benefits the consumer & $\mathbf{0 . 7 1}$ & 0.08 \\
There's nothing wrong with purchasing counterfeit goods & $\mathbf{0 . 6 7}$ & -0.1 \\
Generally speaking, buying counterfeit goods is a better choice. & $\mathbf{0 . 8 8}$ & 0.00 \\
Counterfeits have similar quality to the original version & $\mathbf{0 . 7 8}$ & 0.14 \\
Buying counterfeits infringes intellectual property & 0.20 & $\mathbf{0 . 7 1}$ \\
Buying counterfeits will hurt the industry & 0.04 & $\mathbf{0 . 8 5}$ \\
Buying counterfeits damages interests and rights of legitimate/ original & 0.07 & $\mathbf{0 . 9 2}$ \\
manufacturers & & \\
Purchasing counterfeits is illegal & 0.01 & $\mathbf{0 . 7 6}$ \\
Counterfeit products have the same attributes as the original product & $\mathbf{0 . 6 5}$ & 0.12 \\
Counterfeit products are as reliable as original branded products & $\mathbf{0 . 7 0}$ & 0.14 \\
\hline
\end{tabular}

Reliability of the Two Extracted Factors (Constructs): Reliability is the consistency of the measurement, or the degree to which an instrument measures the same way each time it is used under the same condition with the same subjects. A Cronbach's alpha value above 0.8 has a very good reliability; a value between 0.6 and 0.8 has an acceptable reliability and a value below 0.6 have an unacceptable reliability. The Cronbach's alpha for the two sub-constructs all yielded high Cronbach alpha values ( $>=0.80$ ) indicating good reliability. The table below represents the distribution of the scores, summary of statistics and Cronbach's alpha values of each of the two constructs.

Table 9: The Distribution of the Scores, Statistics Summary and Cronbach's Alpha

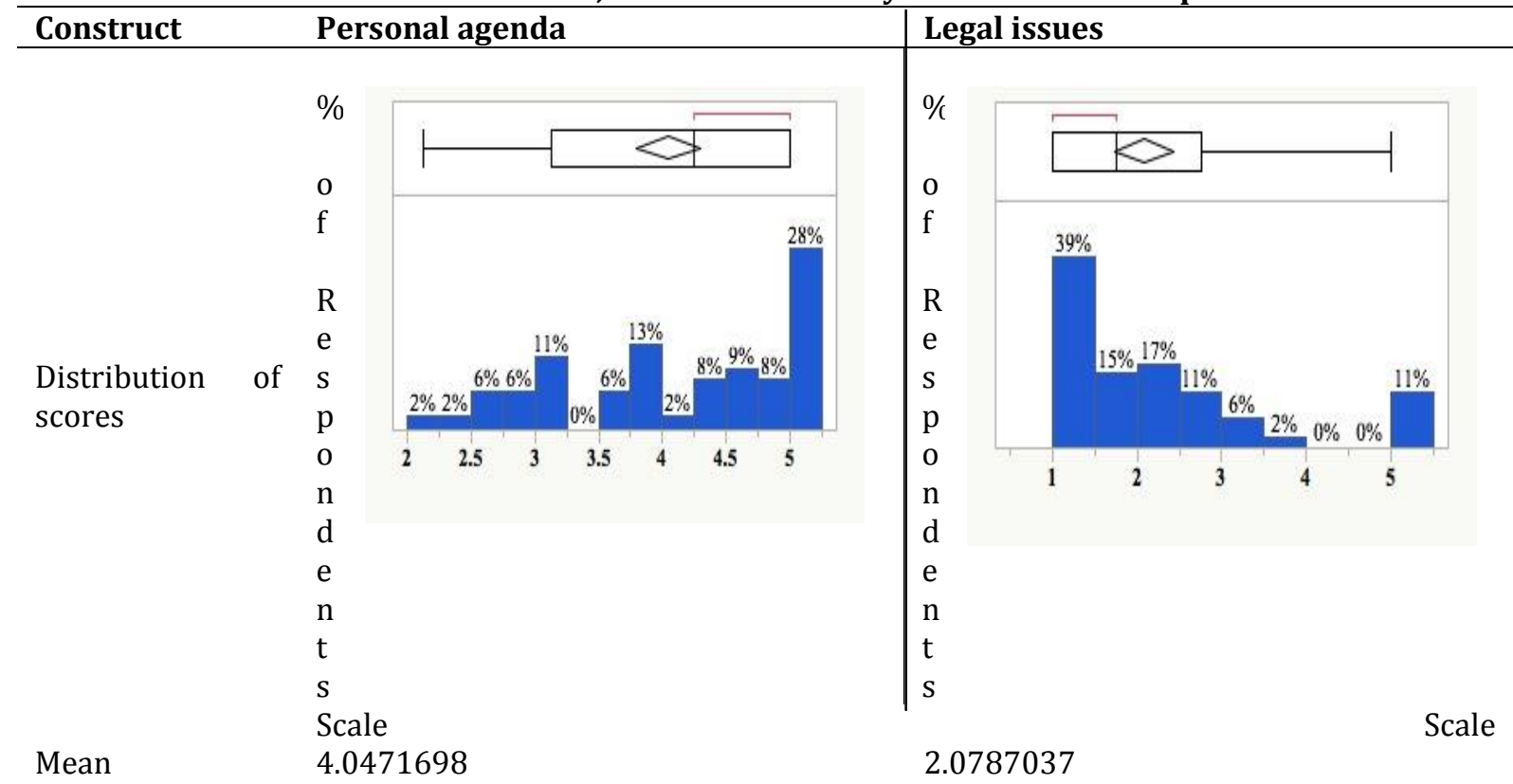

\footnotetext{
3 * Please note that a few of the mentioned statements were derived from De Matos et al (2007) and Riquelme, Abbas \& Rios (2012).
} 


\begin{tabular}{lll} 
Std Dev & 0.907227 & 1.2540727 \\
Std Err Mean & 0.1246172 & 0.1706577 \\
Upper 95\% & 4.2972326 & 0.1706577 \\
Lower 95\% & 3.7971071 & 1.7364078 \\
N & 53 & 53 \\
Cronbach's alpha & 0.91 & 0.88 \\
\hline
\end{tabular}

It is clear from the table that the score for the construct personal agenda is skewed to the right whereas the score for the construct legal issues is skewed to the left. The individual Cronbach's coefficient alpha value of each dimension is used as a measure of the reliability of the tested construct or factor. A reliable Cronbach's coefficient alpha value validates that the individual items of a construct or factor measured the same construct or factor in the same manner (or consistently). Respondents seem to be negative towards counterfeits with 'Personal agenda' the mean is high (4.05) indicating disagreement while the mean for 'Legal issues' is low (2.08) indicating agreement. The standard deviation for 'Legal issues' is higher indicating more variation in agreement among this construct or factor.

Profiling the Views of Respondents on Counterfeits: The biographical variables age, gender, population group, income group, qualification and province were tested against the constructs for significant different views. Of the biographical variables tested no variables showed significantly different views.

\section{Conclusion and Recommendations}

The International Trademark Association (INTA, 2014) defines the concept of counterfeiting to be the action of producing goods that are on most occasion of lesser quality and selling those products illegally under a brand name which the owner of the authentic brand has not authorised. INTA (2014) further indicates that a multitude of industries are affected by counterfeit trade; however one of the most prominent being that of the fashion industry (Harun et al., 2012:15; Phau et al., 2009:3; Phau, Sequeira \& Dix, 2009:262; Ergin, 2010:2181-2186), due to its dominance in one's popular modern cultural psyche (O'Cass \& Frost, 2002:68). With the spread of counterfeiting estimating to top $\$ 1.77$ trillion by 2015 (ICC, 2011), it becomes apparent that more knowledge is needed, in a hope to limit the spread of the industry. This study therefore sought to gain insight into counterfeit purchases and attitudes held by SME owners or individuals wishing to start their own business. The research indicated that majority (12.3 per cent) had previously purchased sunglasses while 11 per cent had purchased watches.

Price is the most important factor followed by design when considering all respondents, however when splitting respondents between those that have bought and those that have not the following pattern emerges. Respondents that have purchased a counterfeit product consider price as the most important factor followed by design. Respondents that have not purchased a counterfeit product consider quality as the most important factor followed by brand loyalty. The research revealed that SME owners do not like shopping for counterfeit goods, they regard a counterfeit as not as reliable as the original branded products and do not think that buying counterfeit goods is a better choice. The SME owners also agree with the statements that buying counterfeits will hurt the industry and that buying counterfeits damage interests and rights of legitimate/original manufacturers. An exploratory factor analysis on the attitude and perception statements revealed two constructs. The first construct addressed personal agenda and the second construct legal issues.

Implications emanating of the research study are that even though there is a negative attitude towards counterfeit purchase among SME owners, those that have purchased counterfeit products in the past indicate the reason for purchase was due to price and design. It is important that original brand owners drive a campaign to highlight the aspect of quality so that consumers of branded products do not purchase these products due to inferior quality. A further implication emanating from the research, is that even though SME owners do agree that the purchase of counterfeit merchandise hurts the industry and damages the interests and rights of the original brand manufacturers, legal systems need to be heightened to ensure further damage to fashion branded merchandise is minimised, thereby reducing the detrimental effect of the illicit industry on the economy. 
Limitations of the research study that need to be addressed and kept in consideration for future research studies, is that the sample consisted mainly of individuals from Mpumalanga and the Western Cape provinces of South Africa, thereby restricting generalisation to the mere population subgroups of South Africa. A further limitation that needs to be addressed is that the response rate was quite small $(n=73)$. Finally the sampling methodology utilised to select the population of interest was that of simple random sampling, this sampling methodology limits the study as all SME owners do not have a known chance of selection into the sample as it is based on random selection within a known sample population. Apart from the stated limitations mentioned, it is recommended that future research studies should expand the study to incorporate all South African SME owners, so as to do a comparative analysis of different provinces and delineate where problem areas in South Africa lie. Furthermore, future research should look to factors that could entice SME owners to purchase counterfeit merchandise. Finally, studies should seek to gain a better understanding as to South African consumers' attitude of counterfeit merchandise and their intentions to purchase counterfeit merchandise in order to gain a deeper understanding as to the South African counterfeit problem from a demand perspective.

\section{References}

Ang, S. W., Cheng, P. S., Lim, E. A. C. \& Tambyah, S. K. (2001). Spot the difference: consumer responses towards counterfeits. Journal of Consumer Marketing, 18(3), 219-235.

Bian, X. \& Moutinho, L. (2009). An Investigation of determinants of counterfeit purchase consideration. Journal of business research, 62, 368-378.

Bian, X. \& Moutinho, L. (2011). Counterfeits and branded products: effects of counterfeit ownership. Journal of Product and Brand Management, 20(5), 379-393.

Bian, X. \& Veloutsou, C. (2007). Consumers' attitudes regarding non-deceptive counterfeit brands in the UK and China. Journal of Brand Management, 4(3), 211-222.

Cant, M. C. (2010). Marketing: An Introduction. Cape Town, South Africa: Juta.

De Matos, C. A., Ituassu, C. T. \& Rossi, C. A. V. (2007). Consumer attitudes toward counterfeits: a review and extension. Journal of Consumer Marketing, 24(1), 36-47.

Eisend, M. \& Schuchert-Güler, P. (2006). Explaining counterfeit purchases: a review and preview. Academy of marketing science review, 12, 1-22. Retrieved from http://www.amsreview.org/articles/eisend12-2006.pdf

Ergin, E. A. (2010). The rise in the sales of counterfeit brands: the case of the Turkish consumers. African Journal of Business management, 4(10), 2181-2186. Retrieved from http://academicjournals.org/AJBM/PDF/pdf2010/18Aug/ Ergin.pdf

Haman, M. (2010). Africa rising to the anti-counterfeit challenge. Journal of Intellectual Property Law \& Practice, 5(5), 344-349.

Harun, A., Bledram, N. A. A. R., Suki, N. M. \& Hussein, Z. (2012). Why customers do not buy counterfeit luxury brands? Understanding the effects of personality, perceived quality and attitude on unwillingness to purchase. Labuan e-Journal of Muamalat and Society, 6, 14-29.

Heike, S. (2010). Effects of counterfeits on the image of luxury brands: an empirical study from the consumer perspective. Journal of Brand Management, 18(2), 159-173. Retrieved from http://www.palgravejournals.com/bm/journal/v18/n2/abs/bm201028a.html

International Anti-Counterfeit Coalition (IACC). (n.d.). The truth about counterfeiting. Retrieved from http://www.iacc.org/about-counterfeiting/the-truth-about-counterfeiting.php

International Chamber of Commerce (ICC) the world business organisation. (n.d). Global impacts study. Retrieved from http://www.iccwbo.org/Advocacy-Codes-and-Rules/BASCAP/BASCAPResearch/Economic-impact/Global-Impacts-Study/

International Trademark Association (INTA). (2014). Fact sheets protecting a trademark. Retrieved from http://www.inta.org/TrademarkBasics/FactSheets/Pages/Counterfeiting.aspx.

Juggessur, J. \& Cohen, G. (2009). Is fashion promoting counterfeit brands? Brand management, 16 (5/6), 383-394.

Kim, H. \& Karpova, E. (2010). Consumer attitudes toward fashion counterfeits: application of the theory of planned behaviour. Clothing and Textiles Research Journal, 28(2), 79-94.

Koklic, M. K. (2011). Non-deceptive counterfeiting purchase behaviour: antecedents of attitudes and purchase intentions. The Journal of Applied Business Research, 27(2), 127-138.

Lan, M., Lui, F., Fang, C. \& Lin, T.M.Y. (2012). Understanding word of mouth counterfeiting. Scientific research: Psychology, 3(3), 289-295. 
The

'Fake'

epidemic.

Retrieved

from http://www.leader.co.za/printarticle.aspx?s=41\&f=1\&a=3321

Lee, S. \& Workman, J. E. (2011). Attitudes toward counterfeit purchases and ethical beliefs among Korean and American University students. Family \& Consumer sciences research journal, 39(3), 289-305.

Magwaza, N. (2012). Clothing sector fights surge in counterfeit products entering SA. Retrieved from http://www.iol.co.za/business/business-news/clothing-sector-fights-surge-in-counterfeit-productsentering-sa-1.1401407

Maldonado, C. \& Hume, E. C. (2005). Attitudes towards counterfeit products: An ethical perspective. Journal of Legal, Ethical and Regulatory Issues, 8(2), 105-117.

Meissner, R. (2010). The trade in counterfeit goods: What is it, why is it a problem and what is its impact on Africa. Retrieved from http://www.polity.org.za/ article/the-trade-in-counterfeit-goods-what-is-itwhy-is-it-a-problem-and-what-is-its-impact-on-africa-2010-08-04

Mir, I. A. (2011). Impact of the word of mouth on consumers' attitude towards the non-deceptive counterfeits. Middle-East Journal of scientific research, 9 (1), 51-56.

Nellis, C. (2011). Faking it: Counterfeit fashion. Retrieved from http://fashion.about.com/cs/tipsadvice/a/fakingit.htm

News24. (2011). Counterfeit industry grows, tops R360bn. Retrieved from http://www.news24.com/SouthAfrica/Politics/Counterfeit-industry-grows-tops-R360bn-20111003

O'Cass, A. \& Frost, H. (2002). Status brands: examining the effects of non-product-related brand associations on status and conspicuous consumption. Journal of Product and Brand Management, 11(2), 67-88. Retrieved from http://www. emeraldinsight.com/journals.htm?articleid=857780\&show=abstract

Penz, E. \& Ströttinger, B. (2005). Forget the "Real" thing-take the copy! An explanatory model for the volitional purchase of counterfeit products. Advances in Consumer Research, 32, 568-575.

Phau, I., Sequeira, M. \& Dix, S. (2009). Consumers' willingness to knowingly purchase counterfeit products. Direct Marketing: An International Journal, 3(4), 262-281.

Phau, I. \& Teah, M. (2009). Devil wears (counterfeit) Prada: a study of antecedents and outcomes of attitudes towards counterfeits of luxury brands. Journal of Consumer Marketing, 26(1), 15-27.

Phau, I., Teah, M. \& Lee, A. (2009). Targeting buyers of counterfeits of luxury brands: a study on attitudes of Singaporean consumers. Journal of Targeting, Measurement and Analysis for Marketing, 17(1), 3-15.

Ramara, P. \& Lamont, M. (2012). Counterfeiting - the perceived victimless crime. Retrieved from http://www.spoor.com/home/index.php?ipkMenuID=\&ipkArticleID=404

Riquelme, H. E., Abbas, E. M. S. \& Rios, R. E. (2012). Intention to purchase fake products in an Islamic country. Education, Business and society contemporary Middle Eastern Issues, 5(1), 6-22.

Sharma, P. \& Chan, R. Y. K. (2011). Counterfeit proneness: Conceptualisation and scale development. Journal of Marketing management, 27(5-6), 602-626.

South African Institute of Intellectual Property Law (SAIIPL). (n.d.). Anti-counterfeiting. Retrieved from http://www.saiipl.org.za/introip/76-anticounterfeiting

Swami, V., Chamorro-Premuzic, T. \& Furnham, A. (2009). Faking it: personality and individual difference predictors of willingness to buy counterfeit goods. The journal of Socio-Economics, 38, 820-825.

Teah, M. \& Phau, I. (2001). Attitudes towards counterfeits of luxury brands: the Singapore story. Journal of Advertising, 1, 1-8. Retrieved from http:// anzmac.info/conference/2008/_Proceedings /PDF/S05_/Teah\%20\%26\%20Phau\% 20S8\%20PS\%20P1.pdf

Turunen, L. L. M. \& Laaksonen, P. (2011). Diffusing the boundaries between luxury and counterfeits. Journal of Product and Brand Management, 20(6), 468-474. Retrieved from http://www.emeraldinsight.com/journals.htm?articleid= 1954076

Vida, I. (2007). Determinants of consumer willingness to purchase non-deceptive counterfeit products. Managing global transitions, 5(3), 253-270.

Yoo, B. \& Lee, S. (2009). Buy genuine luxury fashion products or counterfeits? Journal of Advances in consumer research, 36, 280-286. Retrieved from http://people.hofstra.edu/Boonghee_Yoo /papers/2009_acr_counterfeits.pdf

Yoo, B. \& Lee, S. (2012). Asymmetrical effects of past experiences with genuine fashion luxury brands and their counterfeits on purchase intention of each. Journal of Business Research, 65, 1507-1515.

Zhang, J., Hong, L. J. \& Zhang, R. Q. (2012). Fighting strategies in a market with counterfeits. Ann Opera Res, $192,49-66$. 